\title{
研 究
}

\section{模型試験に基づくプロペラキャビテーション雑音レベルの予測*}

\author{
岡村 尚昭** \\ (石川島播磨重工業侏技術研究所) \\ 浅野 利夫*** \\ (石川島播磨重工業㑣船舶海洋事業本部) \\ (平成 3 年 9 月 26 日受付け)
}

\begin{abstract}
This paper deals with prediction of cavitation noise of full scale ship's propeller from model experiment and its comparison with full scale measurements performed on two ships, a cargo liner and a training ship. It is proposed to estimate separately the tonal noise and the broadband noise because of their different mechanisms of noise generation. The acoustic-mechanical reciprocity principle is applied for estimating the tonal noise, and for the broadband noise a semi-empirical formula is applied for estimation in low frequencies. Full scale measurements on actual ship were arranged to acquire far-field noise and to eliminate extraneous noise reflected from sea surface. The comparison between predictions and full scale measurements has shown agreement amply proving that the proposed method of cavitation noise prediction is valid for practical purposes.
\end{abstract}

\section{1. はじめに}

海洋調查・開発にたずさわる船や艦艇及び漁船などで は、音源探查, 水中通信, 水中物体の探知などのため水 中音響機器を用いるが，その音響機器の障害となってい るあのに船の水中放射雑音があり，近年これをいかに低 減するかが重要な課題となっている1-5)。

本論文では, 船の水中放射音の中で最大の雑音源であ るプロペラキャビテーション雑音に焦点を絞りその音源 の強さ,すなわちソースレベルを精度よく予測, 計測す る方法を考察する。なお，乙こでソースレベルとは自由 音場におけるプロペラの遠距離雑音を, 音源中心から 1 mの距離に換算した音圧レベルである。

プロペラキャビテーションによる放射雑音は通常成因 によって次の 2 つに分類 ${ }^{6-9)}$ できる。

1. プロペラが船尾伴流中で作動するため発生する、非 定常なキャビティの体積変化に起因した“音色のある雑 音6)”（翼周波数の線スペクトルとその高調波線スペクト ルからなる雑音で, 以降 “音色雑音”之呼ぶ)。

2. 多数のキャビテーション気泡が個々にランダムに崩

* Prediction of propeller cavitation noise level based on model tests.

** Naoaki Okamura (Research Institute Ishikawajima-Harima Heavy Industries Co., Ltd.) Toshio Asano (Ship \& Offshore Ishikawajima-Harima Heavy Industries Co., Ltd。)
壊することにより発生する，連続スペクトルからなる “広帯域雑音”。

てれらの特性を持つプロペラ雑音の予測法としては, キャビテーション水槽や減圧試験水槽における模型試験 による方法と，理論計算による方法があり，現在は前者 が主で後者はまだ実施例む少なく予測法としてまだ不完 全な状態にある。

模型試験法についてみると，特性の異なる音色雑音と 広帯域雑音をそれらの特性にあわせて計測する必要があ るが, 現状は各水槽でそれぞれ異なった方法がとられて おり試験法として統一されていない。また，水槽におい て音響計測を行う場合，一般に低周波数域では水槽の背 景雑音レベルが高いため $\mathrm{S} / \mathrm{N}$ が低い, 水槽は閉ざされ た非常に残響性の高い音場であるなどの問題があるが, これらの問題を十分吟味していないてとが多い。模型音 圧レベルを実船レベルに換算する尺度修正法に関しても， 既発表論文 $\left.{ }^{4-5)}, 10-12\right)$ をるる, 音色雑音と広帯域雑 音に分けて行うケース, 周波数域を幾つかに分けて行う ケース，全体を一つの修正式で修正するケースがあるな ど統一されていないのが現状である。

予測結果を検証する実船デー夕は信頼性と精度が必要 であるが，予測との比較を示した今までの実船計測例 ${ }^{3}$ 5), (0), 11), 13) をみると, 海面からの反射波の影響 (Lloyd Mirror 影響》) が考慮されてなかったり, 近距離音場 で計測したりして計測精度上問題を含んでいる。 
本論文では模型試験に基づいた新たな予測法と精度の よい実船計測法を示すと共に，2隻の船について実際に 予測と実船計測を行い, 提案した推定法の評価を行う。

\section{2. 模型試験に基づくプロペラキャビテーション雑音 の推定法}

キャビテーション水槽における模型試験結果から実船 のプロペラキャビテーション雑音を推定する試みは, 今 までにいくつか見うけられるが3-5),10),111,13)，その方

\section{Blade Rate Tones}

Broadband Noise

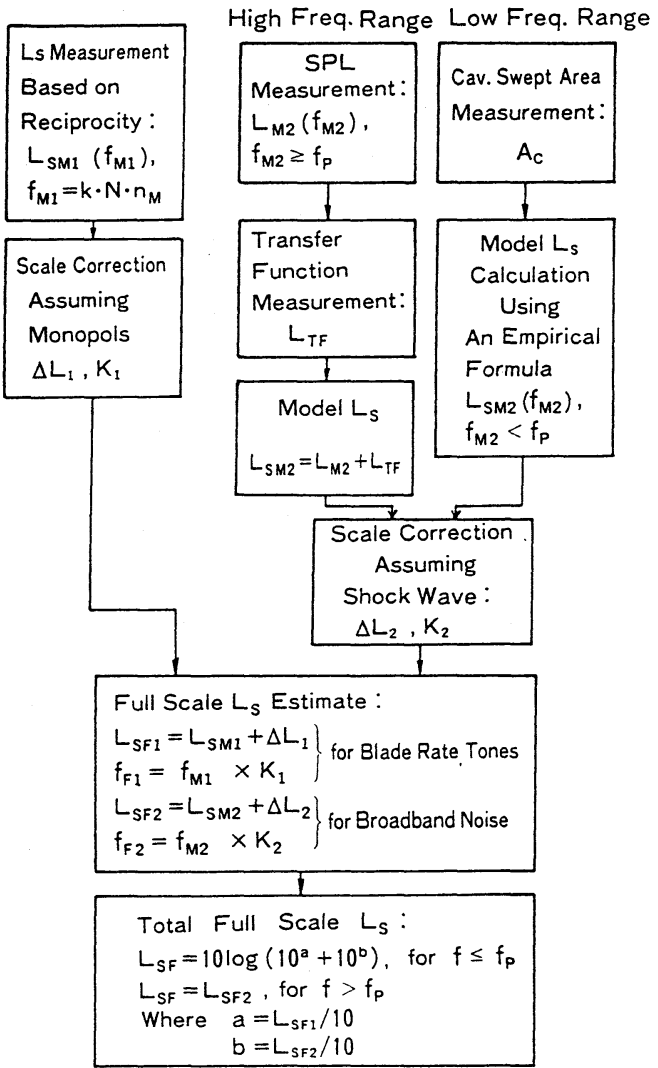

図 1 模型試験により実船プロペラのキャビテーション 雑音を推定するフロー

Ls:ソースレベル, SPL：音圧レベル

$\mathrm{N}$ : 翼数,

$\mathrm{k}$ : 正整数

$\mathrm{n}_{\mathrm{M}}$ : 模型プロペラ回転数, $\mathrm{f}_{\mathrm{P}}:$ ピーク周波数

添字 $1 \& 2$ : 音色雑音 \&広帯域雑音
法はまだ十分確立されてはいない。例えば，ITTC でむ 指摘されているように ${ }^{14)}$, 非常に残響性の高い水槽内で の音響試験に重要な水槽一自由音場間の伝達関数の考慮, 適正な尺度修正法, 質の高い実船デー夕との比較検討な どの課題か残されている。そてで，乙てでは以上のよう な問題点の改善を意図した模型試験による推定法を提案 する。

プロペラキャビテーション雑音は前述のように音色雑 音と広帯域雑音の 2 つの基本タイプに分けられるので, 以下ではこれらの両タイプの雑音をそれぞれの特性に基 づいて模型試験により推定する方法を述べる。その推定 のフローを図1に示す。

\section{1 音色雑音の推定}

(1) 模型試験法

模型試験に扔いて，音色雑音の周波数は通常 100 600 $\mathrm{Hz}$ 程度と低くその波長は $15 \sim 2 \mathrm{~m}$ のオーダであり，乙 の波長は通常のキャビテーション水槽, 例えばIHI水槽 ${ }^{15)}$ の計測部サイズ $600 \times 600 \mathrm{~mm}$ に比べはるかに大きい。ま た，水槽の背景雑音も一般に低周波域で高くなる。この ため, 通常の水槽で模型試験により直接, 音色雑音を精 度よく計測することは難しい。

そこで, 非定常キャビティの体積変化汇起因する音色 雑音を計測, 推定するにあたり, 音響的観点からその特 性を再考する。音色雑音の最低次周波数である翼周波数 は通常, 実船で $5 \sim 10 \mathrm{~Hz}$ のオーダであるからその 5 次 までの音色雑音の波長は $30 \mathrm{~m}$ 以上であり, プロペラの 直径はてれに比べて十分小さい。また，実船プロペラの キャビティの体積（1 翼）は，ステレオ写真を用いた実 測 ${ }^{16)}$ 亿よると大型タンカーで約 $0 \sim 2.5 \times 10^{6} \mathrm{~mm}^{3}$ の変 化を示しており，乙れを球におきかえると最大直径が $170 \mathrm{~mm}$ の球形キャビティに相当する。また青雲丸の実 船試験例 ${ }^{17)}$ ではこれが各々, $0 \sim 14 \times 10^{6} \mathrm{~mm}^{3}$, 直径 300 である。音源のサイズをこのオーダと考えるとそれ は音色雑音の波長に比べ十分小さく，従って音色雑音の 発生機構はモノポール，すなわち音の波長に比べそのサ イズが十分小さいバブルの体積変動によるものと考える ことができる。

とのように，音色雑音はモノポール的音源によるもの で，乙れはプロペラ起振力で言うプロペラ変動圧力に相 当し, その圧力は水槽壁上の各点で位相がそろい壁に大 きな力を及ぼす。しかしその他のプロペラ荷重や翼の肉 厚等による雑音はダイポール的雑音であり, その圧力は 壁面上の場所によって位相が異なるため, 全体として打 ち消しあって起振力としては小さくなる。

そこで，乙こでは問題の多い音響計測に代えて音響機 
械的相反原理 ${ }^{18)}$ に基づき, 音色雑音により振動する水 槽計測部観測空の加速度を計測する方法を用いる。プロ ペラ作動時の観測空のある点の加速度を $a_{1}$ とし，また プロペラ停止状態でその加速度計測点に加振力 $\mathrm{F}_{2}$ を加 えた時プロペラ位置で計測した受波音圧を $\mathrm{P} 2$ とする。 すると音響機械的相反原理により，プロペラキャビティ の体積 $\mathrm{V}_{\mathrm{c}}$ の変化率即ち体積速度 $\mathrm{dV}_{\mathrm{c}} / \mathrm{dt}$ は次式で与え られる。

$$
\frac{\mathrm{dV} \mathrm{c}}{\mathrm{dt}}=\frac{\mathrm{F}_{2}}{\mathrm{P}_{2}} \cdot \frac{\mathrm{a}_{1}}{\omega}
$$

一方, モノポールによる放射雑音の音圧 P は次式で与え られる191。

$$
P(r, t)=\frac{\rho}{4 \pi r} \cdot \frac{d^{2} V_{c}}{d t^{2}}
$$

$$
\begin{aligned}
\text { こてで, } & \mathrm{r}: \text { 音源中心からの距離 } \\
\mathrm{t} & \text { 時間 } \\
& \rho: \text { 流体密度 }
\end{aligned}
$$

また, 角速度 $\omega$ で变化する体積速度 $d V_{c} / d t$ のモノポー ルによる音圧は（2）式より

$$
\mathrm{P}=\frac{\rho}{4 \pi \mathrm{r}} \cdot \omega \frac{\mathrm{dV_{ \textrm {C } }}}{\mathrm{dt}}
$$

となる。こてでソースレベルを L L とすると， Ls はその 定義より次式で表現される。

$$
\left.\mathrm{L}_{\mathrm{s}}=10 \log \left(<\mathrm{P}^{2}\right\rangle \mathrm{r}^{2}\right)
$$

ここで, $<>$ : 自乗平均, $\mathrm{r}$ : in $\mathrm{m}$

$\log : \log _{10}=$ 常用対数（以下同様）

従って,（1），（3），（4）式より Ls は次式で計算でき る。

$$
\mathrm{L}_{\mathrm{s}}=10 \log \left\{\left(\frac{\rho}{4 \pi}\right)^{2}\left\langle\mathrm{~F}_{2}{ }^{2}\right\rangle\left\langle\mathrm{a}_{1}{ }^{2}\right\rangle\left\langle\mathrm{P}_{2}{ }^{2}\right\rangle\right\}
$$

ここでは, Ls を $1 / 3$ オクターブバンドレベルとし, 観 測空は白色雑音で加振してその時の加振力 $\mathrm{F}_{2}$ と受波音 圧 $\mathrm{P}_{2}$ は 1 ／ 3 オクターブバンドでスペクトル解析する。 この際, $\mathrm{P}_{2}$ の計測はプロペラ円内キャビティ発生域内の 代表的な数点で行い, その結果をパワー平均する。本試 験装置の概要を図 2（1）に示す。

（2） 尺度修正法

模型試験をキャビティ形状の相似条件下 ${ }^{81}$ すなわち, 幾何学的相似プロペラ, 相似伴流, 同一プロペラ前進率, 同一キャビテーション数, 気泡核・レイノルズ数の補正 (空気含有量・前緑粗度等) で行う。翼周波数は翼数と
プロペラ回転数の積であるから実船と模型の周波数の比 K 1 は次式となる。

$$
K_{1}=\frac{f_{F}}{f_{M}}=\frac{n_{F}}{n_{M}}
$$

ここで, 添字 1 は音色雑音を意味する。

キャビティ体積速度 $\mathrm{dV}_{\mathrm{c}} / \mathrm{dt}$ はキャビティ体積 $\mathrm{V}_{\mathrm{c}}$ と 周波数 $\mathrm{f}$ の積に比例するから

$$
\frac{d V_{c}}{d t} \sim V f \sim D^{3} f
$$

と仮定できる。従って, 実船と模型の間には次式が成立 する。

$$
\frac{\left(\frac{d V_{C}}{d t}\right)_{F}}{\left(\frac{d V_{C}}{d t}\right)_{M}}=\left(\frac{D_{F}}{D_{M}}\right)^{3} \cdot \frac{f_{F}}{f_{M}}=\lambda^{3} \frac{n_{F}}{n_{M}}
$$

ここで $\rho_{\mathrm{F}}=\rho_{\mathrm{M}}$ と仮定すると，(3)，(8) 式より実船 と模型のソースレベルの差 $\triangle \mathrm{L}_{1}$ は次式となる。

$$
\begin{aligned}
\triangle L_{1} & =L_{S F}-L_{S M} \\
& =10 \log \left\{\left(\frac{\rho_{F}}{\rho_{M}}\right)^{2}\left(\frac{n_{F}}{n_{M}}\right)^{4} \lambda^{6}\right\} \\
& =10 \log \left\{\left(\frac{n_{F}}{n_{M}}\right)^{4} \lambda^{6}\right\}
\end{aligned}
$$

\section{2 広帯域雑音の推定}

(1) 模型試験法

キャビテーション水槽で, プロペラキャビテーション による広帯域雑音を計測する場合の大きな問題として下 記が挙げられる。

1. 受波器が音源に近い場合, 近距離雑音を大きく計測 し，目的とする遠距離雑音と異なってくる。

2. 水槽囲壁からの反射音も同時に計測するため, 目的 とする自由音場音とは異なってくる。

3. 低周波数域では水槽計測部寸法や音源一受波器間の 距離に比べ波長が大きくなり意味のある計測が困難とな る上, 背景雑音レベルも高い。

ここではこれら第 1 , 第 3 の問題を解決するため, 低 周波数域の広帯域雑音を推定するに下記の Brown の半 経験式201を用い, その中でキャビテーション掃引面積 $A_{c}$ を模型試験から求める。

$$
\begin{gathered}
L_{\mathrm{S}}=163+10 \log \left\{\mathrm{ND}^{4} \mathrm{n}^{3} \mathrm{f}^{-2}\right\}+10 \log \left(\frac{\mathrm{A}_{\mathrm{c}}}{\mathrm{Add}_{\mathrm{d}}}\right) \\
\left(\mathrm{dB} \mathrm{re} 1 \mu \mathrm{Pa} \cdot \frac{\mathrm{m}}{\mathrm{Hz}^{1 / 2}}\right)
\end{gathered}
$$


こてで, $\mathrm{N}$ : 翼数, $\mathrm{D}$ in $\mathrm{m}, \mathrm{n}$ in $1 / \mathrm{sec}, \mathrm{f}$ in $\mathrm{Hz}$, $\mathrm{A}_{\mathrm{c}}$ : プロペラ円内キャビテーション掃引面積 $\mathrm{A}_{\mathrm{d}}:$ プロペラ円面樍 なお，(10）式の適用範囲は $\mathrm{f}_{\mathrm{p}}<\mathrm{f}<10 \mathrm{KHz}$ であり, $\mathrm{f}_{\mathrm{P}}$ は広帯域雑音スペクトルがピークを示す周波数である。 $\mathrm{f}_{\mathrm{P}}$ はプロペラキャビテーションの程度や船の種類等によ って変り通常 $40 \sim 300 \mathrm{~Hz}$ の間にあるが，乙こではてれ をポンプのキャビテーション雑音に関して用いられてい る次式 ${ }^{211}$ にり与える。

$$
\begin{aligned}
\mathrm{f}_{\mathrm{P}}= & \frac{4400}{\mathrm{D}} \cdot\left(\frac{\sigma_{\mathrm{n}}^{\mathrm{i}}}{\sigma_{\mathrm{n}}}\right)^{-3.2 / 2}\left(\frac{\mathrm{P}_{\mathrm{S}}}{22}\right)^{1 / 3} \\
& \text { for }\left(\frac{\sigma_{\mathrm{n}}{ }^{\mathrm{i}}}{\sigma_{\mathrm{n}}}\right)^{1 / 2}<1.7 \\
\mathrm{f}_{\mathrm{P}}= & \frac{1100}{\mathrm{D}} \cdot\left(\frac{\sigma_{\mathrm{n}}{ }^{\mathrm{i}}}{\sigma_{\mathrm{n}}}\right)^{-2.0 / 6}\left(\frac{\mathrm{P}_{\mathrm{S}}}{22}\right)^{1 / 3} \\
& \text { for }\left(\frac{\sigma_{\mathrm{n}}{ }^{\mathrm{i}}}{\sigma_{\mathrm{n}}}\right)^{1 / 2}>1.7
\end{aligned}
$$

こてで

$\mathrm{f}_{\mathrm{P}}:$ ピーク周波数 $(\mathrm{Hz})$

$$
\begin{aligned}
& \sigma_{\mathrm{n}}=\frac{\mathrm{Ps}_{\mathrm{s}}-\mathrm{P}_{\mathrm{v}}}{\frac{1}{2} \rho(\mathrm{nD})^{2}}: \text { キャビテーション数 } \\
& \mathrm{Ps}_{\mathrm{s}}: \text { 静压 }(\mathrm{psi}) \\
& \mathrm{P}_{\mathrm{v}}: \text { 蒸気压 } \\
& \sigma_{\mathrm{n}}{ }^{\mathrm{i}}: \text { 初生キャビテーション数 }
\end{aligned}
$$

であり， $\sigma_{\mathrm{n}}{ }^{\mathrm{i}}$ は文献 $^{21)}$ を参考にして次式より求める。

$$
\frac{\mathrm{A}_{\mathrm{c}}}{\mathrm{A}_{\mathrm{d}}}=\frac{\left\{\left(\frac{\sigma_{\mathrm{n}}^{\mathrm{i}}}{\sigma_{\mathrm{n}}}\right)^{1 / 2}-1\right\}^{2}}{\frac{\sigma_{\mathrm{n}}{ }^{\mathrm{i}}}{\sigma_{\mathrm{n}}}}
$$

上記の周波数領域外では, Brown は $\mathrm{L}_{\mathrm{s}}$ の周波数依存 性を $\mathrm{f} \leqq \mathrm{f}_{\mathrm{P}}$ では周波数に関係なく一定, $\mathrm{f} \geqq 10 \mathrm{kHz}$ では $f^{-1}$ 亿比例すると仮定している。

第 2 の問題に関しては, 水槽一自由音場間の伝達関数 を実験的に求め, それを用いて水槽で計測したプロペラ キャビテーション雑音を自由音場相当レベルに変換する。 以上の点を考慮した広帯域雑音の推定のフローを図 1 亿, 試験装置図を図 2（2），（3）に示す。以下に本試験法に ついて説明する。

まず，流れを止めた状態でプロペラの代わりに自由音 場で校正した送波器を置いて発信し, それを同じ受波器 で受信する。こてで, 送波器の発信はプロペラ円内のキ ヤビテーション域を代表する数点で行い, その各々の受

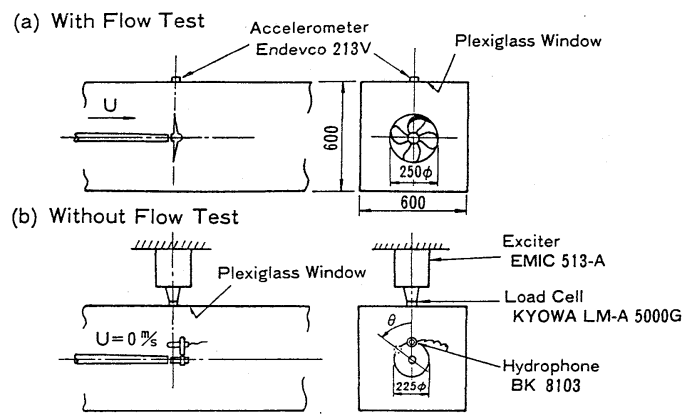

(1)

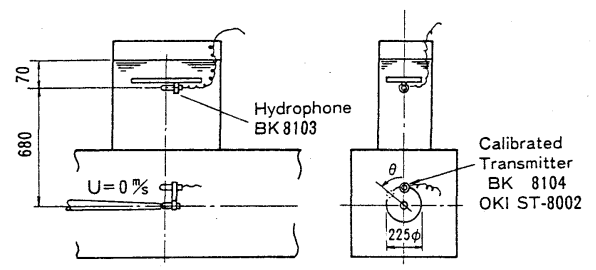

(2)

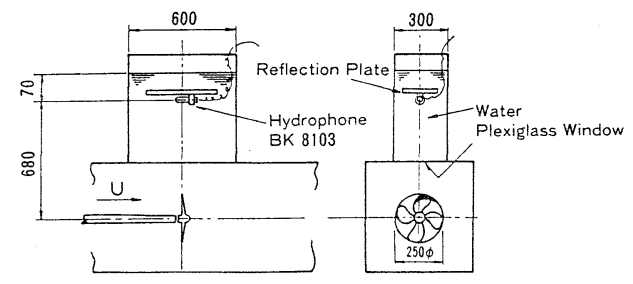

(3)

図 2 プロペラキャビテーション雑音の模型試験装置 (単位 $: \mathrm{mm}$ )
(1) 音色雑音計測
(2) 伝達関数計測
（3）広帯域雑音計測

波レベルをパワー平均したあのを $\mathrm{L}_{\mathrm{b}}$ とする。また，既 知の自由音場特性と印圧電圧より求まる送波器ソースレ ベルを $\mathrm{L}_{\mathrm{a}}$ とすると，伝達関数 $\mathrm{L}_{\mathrm{TF}}$ は

$$
\mathrm{L}_{\mathrm{TF}}=\mathrm{L}_{\mathrm{a}}-\mathrm{L}_{\mathrm{b}}
$$

で表わされる。次に，実船と相似キャビティ発生状態の キャビテーション雑音を計測しその音圧レベルを $\mathrm{L}_{\mathrm{M}}$ と する。すると, 自由音場に換算した模型のソースレベル

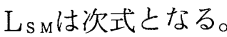

$$
\mathrm{L}_{\mathrm{SM}}=\mathrm{L}_{\mathrm{M}}+\mathrm{L}_{\mathrm{TF}}
$$

（2） 尺度修正法

キャビテーションによる広帯域雑音を Levkovskii ${ }^{22}$ 
と同様に衝撃波ノイズと仮定する。すると実船と模型の 間に次の関係が成立する。

$$
\begin{aligned}
& \frac{\mathrm{f}_{\mathrm{F}}}{\mathrm{f}_{\mathrm{M}}}=\frac{\mathrm{D}_{\mathrm{M}}}{\mathrm{D}_{\mathrm{F}}}\left(\frac{\rho_{\mathrm{M}}}{\rho_{\mathrm{F}}}\right)^{1 / 2}\left(\frac{\triangle \mathrm{P}_{\mathrm{F}}}{\triangle \mathrm{P}_{\mathrm{M}}}\right)^{1 / 2} \\
& \frac{\mathrm{G}_{\mathrm{F}}}{\mathrm{G}_{\mathrm{M}}}=\left(\frac{\mathrm{r}_{\mathrm{M}}}{\mathrm{r}_{\mathrm{F}}}\right)^{2} \frac{\rho_{\mathrm{F}}}{\rho_{\mathrm{M}}}\left(\frac{\mathrm{D}_{\mathrm{F}}}{\mathrm{D}_{\mathrm{M}}}\right)^{3} \frac{\triangle \mathrm{P}_{\mathrm{F}}}{\triangle \mathrm{P}_{\mathrm{M}}}
\end{aligned}
$$

ここで, $\mathrm{G}$ ：音圧のパワースペクトル

$$
\triangle \mathrm{P}=\mathrm{P}_{\mathrm{S}}-\mathrm{P}_{\mathrm{v}}
$$

今，パワースペクトル Gより相似キャビティ条件と $\rho_{\mathrm{F}}=$ $\rho_{\mathrm{M}}$ の仮定のもとに 1 ／ 3 オクターブバンドソースレベル を求める。バンド幅 $\triangle \mathrm{f}$ は中心周波数に比例するから実 船と模型のソースレベルの差 $\triangle L_{2}$ は

$$
\begin{aligned}
\triangle \mathrm{L}_{2} & =\mathrm{L}_{\mathrm{SF}}-\mathrm{L}_{\mathrm{SM}} \\
& =10 \log \frac{\mathrm{G}_{\mathrm{F}} \cdot \Delta \mathrm{f}_{\mathrm{F}} \cdot \mathrm{r}_{\mathrm{F}}{ }^{2}}{\mathrm{G}_{\mathrm{M}} \cdot \Delta \mathrm{f}_{\mathrm{M}} \cdot \mathrm{r}_{\mathrm{M}}{ }^{2}} \\
& =10 \log \left\{\left(\frac{\rho_{\mathrm{F}}}{\rho_{\mathrm{M}}}\right)^{2} \lambda^{5}\left(\frac{\mathrm{n}_{\mathrm{F}}}{\mathrm{n}_{\mathrm{M}}}\right)^{3}\left(\frac{\sigma_{\mathrm{nF}}}{\sigma_{\mathrm{nM}}}\right)^{3 / 2}\right\} \\
& =10 \log \left\{\lambda^{5}\left(\frac{\mathrm{n}_{\mathrm{F}}}{\mathrm{n}_{\mathrm{M}}}\right)^{3}\right\}
\end{aligned}
$$

となる。乙こで, 添字 2 は広帯域雑音を意味する。

また実船と模型の周波数の比 $\mathrm{K}_{2}$ は相似キャビティ条件 下で次式となる。

$$
\begin{aligned}
\mathrm{K}_{2} & =\frac{\mathrm{f}_{\mathrm{F}}}{\mathrm{f}_{\mathrm{M}}} \\
& =\frac{\mathrm{n}_{\mathrm{F}}}{\mathrm{n}_{\mathrm{M}}}\left(\frac{\sigma_{\mathrm{nF}}}{\sigma_{\mathrm{n} M}}\right)^{1 / 2} \\
& =\frac{\mathrm{n}_{\mathrm{F}}}{\mathrm{n}_{\mathrm{M}}}
\end{aligned}
$$

\section{3. 実船計測法}

信頼性があり精度の高い実船データを得るために, 次 のような計測法を提案する。その計測要領を図 3 亿示す。 1. 試験海域：水深が十分深くて球面拡散音場とみなせ かつ海底からの反射影響が無視でき，他の船舶等による 背景雑音が低い場所を選定する。

2. 海象：波が穏かで波浪による雑音も小さく受波器の 摇れも少ない状況を選ぶ。

3. 受波器設置法 : 定速直進状態の航路から横に十分離 れた位置にブイを浮べ，その下に垂直方向に複数個の受 波器を取り付ける。乙れは, 1 個の受波器のみでは, 特 定の周波数でプロペラからの直接波と海面からの反射波

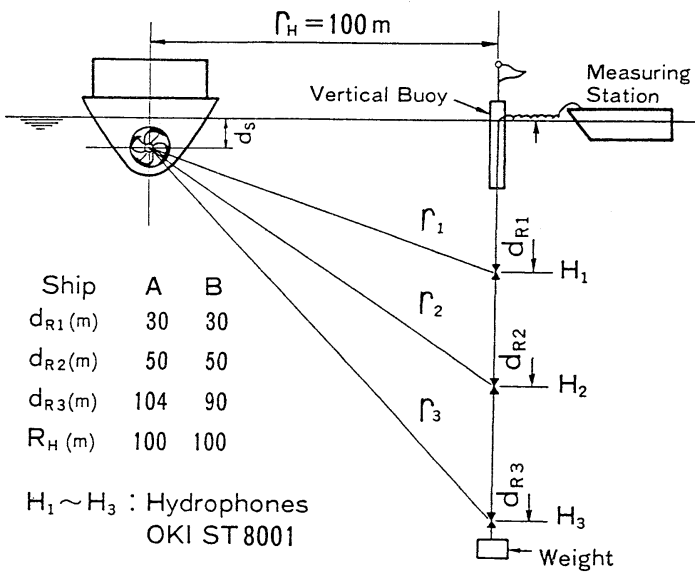

図 3 実船ノイズ計測配置図

との位相干渉の影響（Lloyd Mirror 影響）が大きく出 て正確な計測ができないためであり, 多数個の受波器に より干渉影響の大きい周波数をずらし，それらの出力を 平均するてとによって正確な計測が可能となる。

4. 距離補正 : 音源と受波器間の距離を正確に計測し, 音圧に距離補正を行ってソースレベルを求める。

5. 水中音計測：船速が十分安定した状態で船が受波器 の真横に来る前後で行う。更に, 海流等の影響を除去し 信頼性あるデータを得るため, 何回かの往復航走を行っ てその結果を平均する。

6. ソースレベル計算式：計測結果から最終的に次式に よりプロペラキャビテーション雑音のソースレベルを求 める。

$$
\mathrm{L}_{\mathrm{S}}=\mathrm{L}-\mathrm{L}_{\mathrm{L} M}+20 \log \mathrm{r}
$$

ここでは, Lは受波音压レベル，20 log $\mathrm{r}$ は音源から 1 $\mathrm{m}$ の距離の音圧レベルへの補正, $L_{\mathrm{L} M}$ は海面下の音場か ら自由音場への補正 (Lloyd Mirror 修正 ${ }^{7)}$ ) で次式で 示される。

$$
L_{L M}=10 \log \left\{1+\mu^{2}-2 \mu \cos \left(4 \pi \frac{f d_{S} d_{R}}{c r}\right)\right\}(20)
$$

ここで, $\mu$ : 海面反射による音波の振幅減少係数

$\mathrm{d}_{\mathrm{s}}$ : 音源中心の没水深度

$\mathrm{d}_{\mathrm{R}}$ : 受波器の没水深度

$\mathrm{c}$ : 海水中の音速

$\mathrm{r}$ : 音源一受波器間の距離

$\mu$ は海面が鏡面であれば $\mu=1$ で,一般には海面粗さの 関数であり，ここでは海面粗さがガウス分布をむつもの 
として得られる次式 ${ }^{23)}$ により

$$
\mu=\exp \left\{-2(\kappa \mathrm{h} \cos \theta)^{2}\right\}
$$

ここで, $\kappa:$ 波数

$$
\begin{aligned}
& \mathrm{h}: \text { 海面波の波高（RMS） } \\
& \theta=\tan ^{-1}\left(\frac{\mathrm{r}_{\mathrm{H}}}{\mathrm{d}_{\mathrm{S}}+\mathrm{d}_{\mathrm{R}}}\right) \\
& \mathrm{r}_{\mathrm{H}}: \text { 音源一受波器間の水平距離 }
\end{aligned}
$$

\section{4. 予測及び実船計測結果と考察}

\section{1 供試船}

プロペラキャビテーション雑音の推定と実船計測に供 した船は, 貨物船と練習船の 2 隻であり, その主要目を 表 1 亿, 一般配置図を図 4 に示す。

\section{2 予測及び実船試験条件}

模型試験条件を表 2 亿示す。模型試験は IHI キャビテ ーション水槽に执いて $600 \times 600 \mathrm{~mm}$ 計測筒を用いて行わ れた。実船試験条件を表 3 亿, 実船計測要領を図 3 亿示

\begin{tabular}{|c|c|c|}
\hline SHIP & A & B \\
\hline TYPE & Cargo Liner & Training Ship \\
\hline \multicolumn{3}{|l|}{ HULL } \\
\hline Lpp & $155.45 \mathrm{~m}$ & $46.00 \mathrm{~m}$ \\
\hline Bmld & $22.86 \mathrm{~m}$ & $10.00 \mathrm{~m}$ \\
\hline Dmld & $14.15 \mathrm{~m}$ & $3.80 \mathrm{~m}$ \\
\hline Draft/Full & $10.08 \mathrm{~m}$ & $3.00 \mathrm{~m}$ \\
\hline \multicolumn{3}{|l|}{ MAIN ENGINE } \\
\hline \multirow{2}{*}{\begin{tabular}{l|l|} 
SHP/Rev./Prop. & ROR. \\
\cline { 2 - 3 } & MCR \\
\end{tabular}} & $7020^{\mathrm{PS}} / 520^{\mathrm{r} \mathrm{Pm}} / 130^{\mathrm{rpm}}$ & $1190^{\mathrm{Ps}} / 700^{\mathrm{rpm}} / 200^{\mathrm{rpm}}$ \\
\hline & $7800 \quad / 520 \quad / 130$ & $1400 / 700 / 300$ \\
\hline \multicolumn{3}{|l|}{ PROPELLER } \\
\hline Type & C.P.P.X1 & C.P.P. $\times 1$ \\
\hline Diameter & $5.000 \mathrm{~m}$ & $2.200 \mathrm{~m}$ \\
\hline Pitch Ratio & 0.818 & 0.838 \\
\hline E.A.R. & 0.550 & 0.570 \\
\hline Boss Ratio & 0.260 & 0.264 \\
\hline Skew Angle & $16.0 \mathrm{deg}$ & $28.6 \mathrm{deg}$ \\
\hline Rake Angle & $0.0 \mathrm{deg}$ & $-2.2 \mathrm{deg}$ \\
\hline Number of Blades & 4 & 4 \\
\hline
\end{tabular}
す。試験海域は $600 \sim 1000 \mathrm{~m}$ と水深が十分あり, 周囲雑 音む低い。海象はシーステート 3 で比較的穏やかであり,

\section{表 1 供試船とプロペラの主要目}

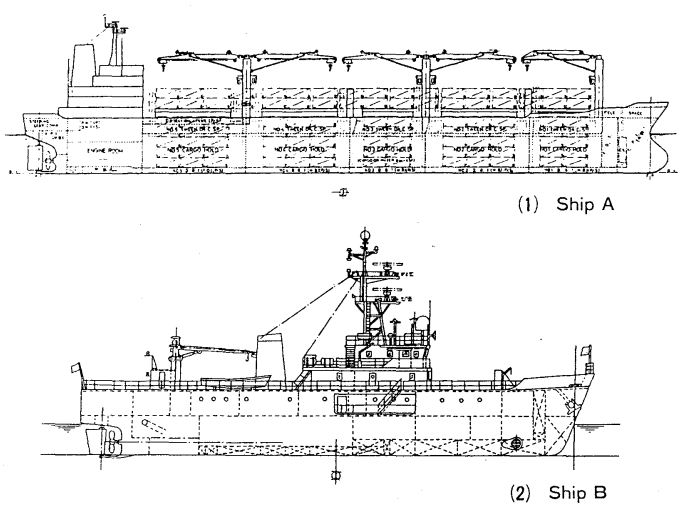

図 4 供試船一般配置図

表 2 模型プロペラ雑音計測試験条件

\begin{tabular}{|l|l|l|}
\hline \multicolumn{1}{|c|}{ SHIP } & \multicolumn{1}{c|}{ A } & \multicolumn{1}{c|}{ B } \\
\hline Load & Ballast/MCR & Full/MCR \\
Prop. Diameter : D & $0.250 \mathrm{~m}$ & $0.250 \mathrm{~m}$ \\
Prop. Revolution : $\mathrm{n}$ & $27.70 \mathrm{rps}$ & $24.10 \mathrm{rps}$ \\
Prop. Thrust Coefficient : $\mathrm{K}_{\mathrm{T}}$ & 0.170 & 0.150 \\
Reproduced $\sigma_{\mathrm{n}}:$ & $1.729^{*}$ & $1.727^{*}$ \\
Reproduced Wake : & 2-D Ship's Wake & do. \\
& by Mesh Screen & \\
Air Content $: \alpha / \alpha \mathrm{S}$ & ab. 55\% & do. \\
\hline
\end{tabular}

*: $\sigma_{\mathrm{n}}$ at $0.9 \mathrm{R}$ top

表 3 実船プロペラ雑音計測試験条件

\begin{tabular}{|l|c|c|}
\hline \multicolumn{1}{|c|}{ SHIP } & A & B \\
\hline SEA CONDITION & & \\
\hline Sea Area & Sagami Bay & Sagami Bay \\
Weather & Cloudy & Cloudy \\
Atmospheric Temp. & $16^{\circ} \mathrm{C}$ & $7{ }^{\circ} \mathrm{C}$ \\
Water Temp. & $13^{\circ} \mathrm{C}$ & $16^{\circ} \mathrm{C}$ \\
Sea State & 3 & 3 \\
Sea Depth & $600 \sim 1000 \mathrm{~m}$ & $600 \mathrm{~m} \sim 1000 \mathrm{~m}$ \\
\hline SHIP CONDITION & & \\
\hline Load & Ballast & Full \\
M/E SHP & $7800 \mathrm{PS}$ & $1388 \mathrm{PS}$ \\
Aft Draft & $5.95 \mathrm{~m}$ & $3.090 \mathrm{~m}$ \\
Ship Speed & $15.7 \mathrm{kt}$. & $14.1 \mathrm{kt}$. \\
Propeller Rev. & $130 \mathrm{rpm}$ & $300 \mathrm{rpm}$ \\
Prop. Shaft Center & $2.750 \mathrm{~m}$ & $1.800 \mathrm{~m}$ \\
Immersion & & \\
\hline
\end{tabular}




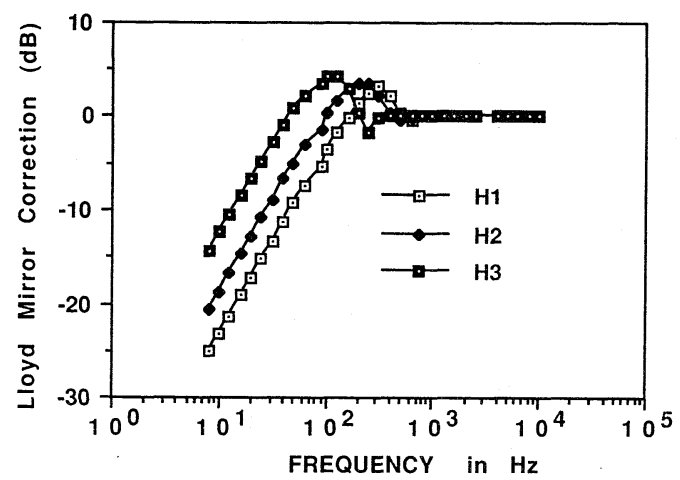

図 5 Lloyd Mirror 修正：A 船
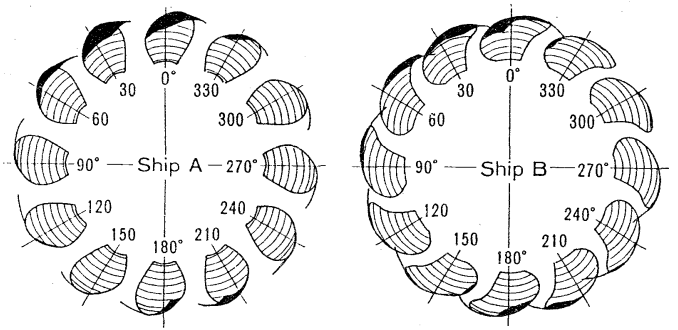

図6 模型プロペラのキャビテーションパターン

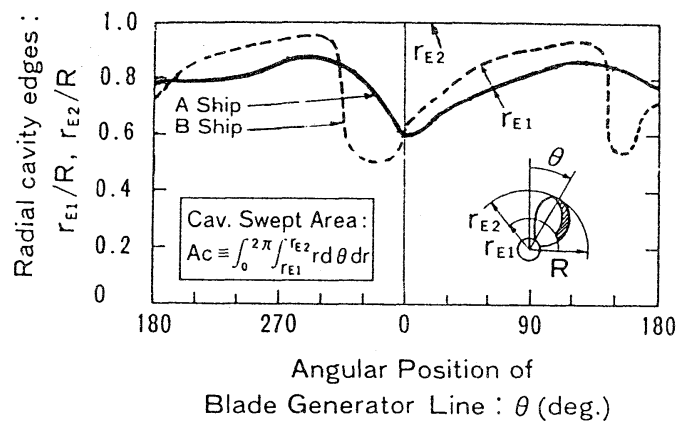

図 7 模型プロペラのキャビティエッジ分布

この状態における海面反射影響 (Lloyd Mirror 修正 (20) 式) はA 船で図 5 亿示すとおりである。

音源と受波器間の距離を求めるため, ここでは, 光学 的な測距儀と測向盤により被計測船とブイとの距離を計 測した。乙の方法による計測誤差の影響は（19）式にお いて約 $0.5 \mathrm{~dB}$ 程度である。受波器は図 3 に示すように 3 個用いた。

\section{3 予測及び実船試験結果と考察}

4.3.1 キャビテーション

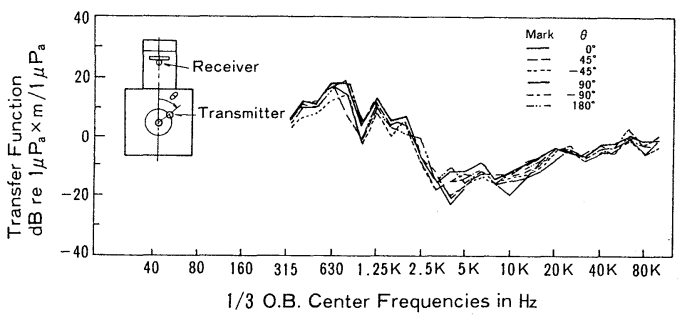

図 $81 \mathrm{HI}$ キャビテーション水槽における 水槽 $/$ 自由音場間の伝達関数計測結果
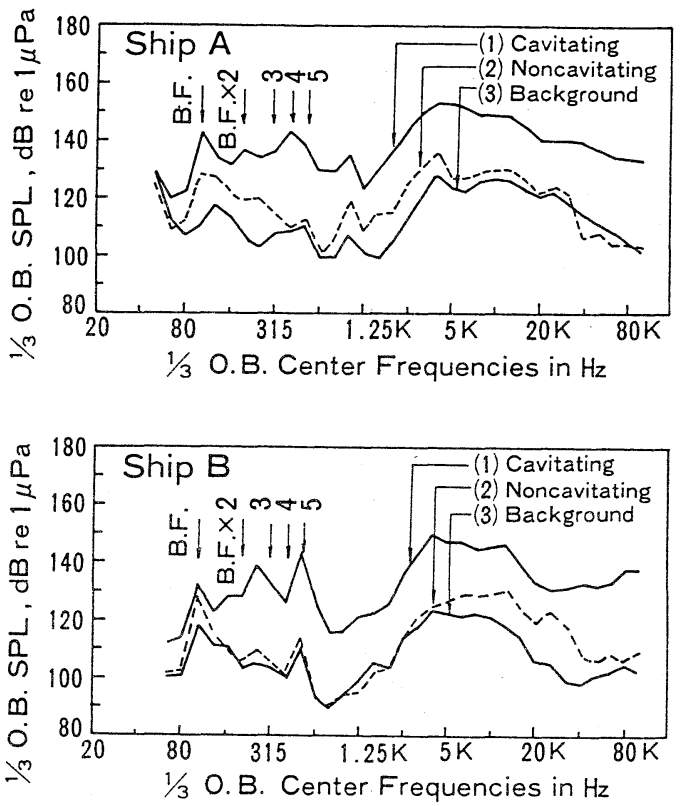

図 $9 \mid \mathrm{HI}$ キャビテーション水槽で計測された 3 状態の模型プロペラ音圧レベル

(1) キャビテーション状態

(2) 非キャビテーション状態

(3) 背景雑音

模型プロペラのキャビテーションパターンを図 6 に示 す。図7にはキャビテーション掃引面積の計算のもとに なるキャビティ端位置の模型試験結果を示す。

\subsection{2 水槽の伝達関数と背景雑音}

図 8 は, IHI キャビテーション水槽計测部の伝達関数 の計測結果である。図中の 6 本のカーブは各々送波器の 回転角位置 6 箇所に対応する伝達関数を示す。予測には これらのパワー平均值を用いた。計測された伝達関数の レベルは最大約 $20 \mathrm{~dB}$ にも達しキャビテーション水槽の 
非自由音場の程度が高く, 模型試験による予測では伝達 関数の考慮が重要であることが分かる。

図 9 は, 計測雑音の $\mathrm{S} / \mathrm{N}$ の程度を表すため, キャビ テーション水槽内に打ける模型プロペラの 3 状態の雑音 レベルを示す。図 9 で状態 (1) は正規の作動条件下,

（2）は（1）の条件のうち静圧のみを上げて非キャビ テーション状態にしたもの，（3）は（1）の条件下で プロペラをダミーボスに取り替えた背景雑音状態を表わ す。 A, B 船ともキャビテーション状態 (1) の音圧レ ベルは低周波数域を除き他の状態（2），(3) に比べ20 $\mathrm{dB}$ 以上大きく，十分な $\mathrm{S} / \mathrm{N}$ を有しているてとが分か る。しかし, 翼周波数の前後では 3 状態の音圧レベルの 差が少なく $\mathrm{S} / \mathrm{N}$ の悪い状態になっている。

\subsection{3 予测と実測結果の比較}

プロペラキャビテーション雑音ソースレベルの予測結 果を, 実船計測結果と比較して図10亿示す。A, B両船 と屯実船航走時の雑音は周囲雑音に比べ $50-60 \mathrm{~dB}$ 高 く非常に $\mathrm{S} / \mathrm{N}$ の良い状態である。なお, 今回の予測・ 実測の周波数範囲は翼周波数から $10 \mathrm{KHz}$ までとした。 なお，前回報告 ${ }^{24)}$ した A 船の実船解析結果では翼周波数 1 次のピークが明確でなかったが, 録音テープを聴くと 明瞭に翼周波数成分が認められた。調査の結果，ハイパ スフィルターカットオフ周波数設定值が高かったことが 分かり，今回フィルターの設定を改めて録音テープを再 解析して明確なピークを得ている。

(1) 音色雑音

推定結果を実測と比較すると, 両船とも最大誤差が約 $5 \mathrm{~dB}$ 以内でかなりよい一致を示している。乙れは, 相反 原理に基づく音色雑音のソースレベルを求める手法が有 用であるととを示すあのである。

\section{(2) 広带域雑音}

予測結果は, 次に述べる問題の周波数域を除き $\mathrm{B}$ 船が 特に良好であり，スペクトル凹凸（B船，f>630 Hz）ま でよく再現している。とてろで, A船の $f>630 \mathrm{~Hz}$ で予 測結果が不自然に約 $10 \mathrm{~dB}$ 程度大きくなっているが，乙 れは水槽内のプロペラ以外の何等かの他のキャビテーシ ョンが関与したためではないかと思われる。また，B船 の $1.25<\mathrm{f}<2.5 \mathrm{KHz}$ で実船計測值に傾向的に不自然な 凸部が見える。乙れは今回往復 2 航走計 4 回の計測を行 って打り, 平均前の 4 回分のソースレベルのうち受波器 の左側を走った時のあのが, その周波数域で特にノイズ が高くなったためである。同じ航路についての計測値の 再現性はよく, 航路による何らかの外的要因の差が影響 したもの之思われる。なお，A船では乙の様な特異な現 象は見られなかった。いずれにしてむ, ての例に示すよ
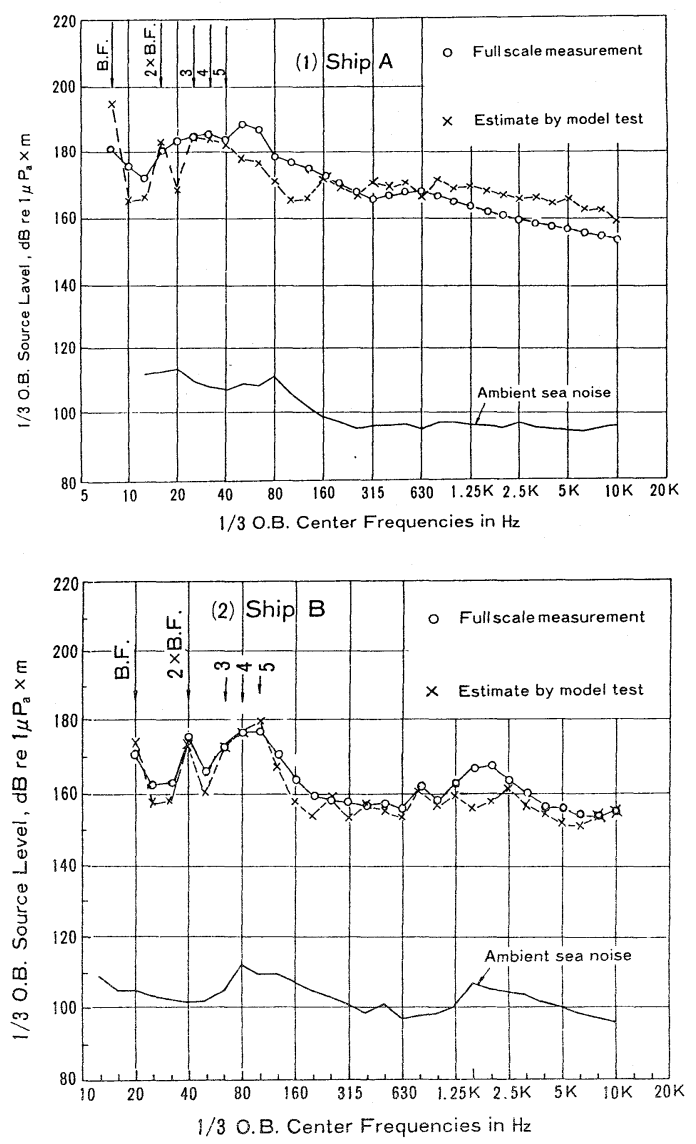

\section{図10 プロペラキャビテーション雑音ソースレベル の予測値亡実測値の比較}

うに実船計測精度をてれ以上良くするてとは非常に難し く，一般には 1 / 3 オクターブバンドレベルで $3-5 \mathrm{~dB}$ の精度を維持するのが精一杯ではないかと思われる。

\section{4 今後の課題}

今後, 更に計測及び予測精度を上げるためには, 実船 計測に拝いてノイズの原因であるプロペラのキャビテー ションをノイズ計測と並行して同時に観測し，まずキャ ビテーション自体の予測と実際との比較・検討を行い, その上で音源モデルや尺度修正法の評価・改善を行うこ とが課題である。

模型試験に関しては, 音響的に設計された背景雑音が 低く残響の少ない大型水槽により，実機に近いサイズの 大型模型を用い $\mathrm{S} / \mathrm{N}$ のよい状態で計測することが望ま しい。最近, 米, 仏, 独で相次いでてのような音響回流 水槽が完成し，その成果が期待されている ${ }^{25-281}$ 。 


\section{5. 結言}

プロペラキャビテーション雑音のソースレベルを合理 的に予測する方法之, 音響的に十分信頼できる実船の雑 音計測方法とに関する今回の研究の結果, 下記の結論を 得た。

(1) プロペラキャビテーション雑音を，全周波数域に わたりその発生機構に合わせ, より合理的に予測するた めには, プロペラ雑音を“音色雑音”と“広帯域雑音”之 に分けて予测するてとが重要である。

（2）模型実験において低周波数域の音響計测上の問題 を解决するために，音色雑音について音響計測に代え振 動計測によりソースレベルを求める方法, 広带域雑音に ついてはキャビテーション掃引面積の計測と雑音推定式 を組み合わせる方法を試み，その実用性を実船試験によ り確認した。

（3）模型試験における水槽一自由音場間の伝達関数は, 最大約 $20 \mathrm{~dB}$ にあ及びソースレベルの推定に打いて伝達 関数の影響は大きく無視できないてとが明らかになっ た。

（4）実船試験において, 音の海面での反射に伴う問題 を解決し信頼性のある計測を可能にした。

(5) 2 隻の実船についての実測と予測とを比較した結 果, 予測值の平均誤差は約 $6 \mathrm{~dB}$ であり, 最大誤差は約 $10 \mathrm{~dB}$ 以内であった。なお, $\mathrm{A}$ 船の経験を生かして行っ たB船についての予測では, 一部の周波数域を除くと最 大誤差は約 $5 \mathrm{~dB}$ まで改善された。

なお, 著者らはこれに関連した理論的推定も行ってお り，それについては文献 ${ }^{24)}$ を参照されたい。

\section{参考文献}

1 ）三橋邦宏他, “半没水型双胴船の水中雑音特性につ いて”，三井造船技報 114，35４3（1982）.

2 ）中西俊之他, “「なつしま」の水中放射雑音低減策 とその実測結果について”, 海洋音響研究会会報 8 (4), 16 27 ( 1981$)$.

3 ) T. Sasajima, N. Nakamura and A. Oshima, "Model and Full Scale Measurements of Propeller Cavitation Noise on an Oceanographic Research Ship with Two Different Types of Screw Propeller", Proc. 2 nd International Symposium on Shipboard Acoustics ISSA' 86, 63〜74 (1986).

4 ) G. Bark, "Prediction of Propeller Cavitation Noise from Model Tests and Its Comparison with Full Scale Data", Journal of Fluids
Engineering", Trans.ASME 107, 112 120 (1985).

5 ) J. Vassenden and A. Lovik, "Prediction of Noise from Cavitating Propellers", NSFI Report R-82.79, 7〜17 ( 1979 ).

6 ) R. J. Urick /土屋明訳, 水中音響の原理 (共立出版, 1978 ), 316 340.

7 ) R.J. Urick, Principles of Underwater Sound (McGraw-Hill, 1975 ), 328〜353.

8 ) 加藤洋治, 笹島孝夫, 岡村尚昭, “プロペラキャビテ ーション試験と起振力・騒音計測”, 船型開発と試 験水槽シンポジウム, 日本造船学会, 159 188 (1983).

9 ) L. M. Gray and D.S. Greeley, “Source Level Model for Propeller Blade Rate Radiation for World's Merchant Fleet", J. Acoust. Soc. Am. 67 (2), 516 522 (1980).

10) O. Bjorheden and L. Astrom, "Prediction of Propeller Noise Spectra”, Symposium on Hydrodynamics of Ship and Offshore Propulsion Systems ( 1977 ).

11) A. Lovik, "Scaling of Propeller Cavitation Noise", Noise Sources in Ships 1: Propellers, NORDFORSK, D1〜D19 ( 1981 ).

12) H. Yuasa, H. Kamiirisa and T. Nojiri, "Study on the Characteristics of Propeller Cavitation and Its Noise", 16 th Symp. on Naval Hydrodynamics, ONR, 371 386 ( 1986 ).

13) A. Nilsson, B. Persson and N. D. Tyvand, "Propeller Induced Noise in Ships", Propellers '81 Symposium, SNAME ( 1981 ).

14) Report of Cavitation Committee, Proc. 18 th ITTC, 303 317 ( 1987 ).

15) S. Nishiyama, N. Okamura and R. Sato, "Outline of the New IHI Cavitation Tunnel", IHI Engineering Review 13 ( 2), 7〜 13 ( 1980 ).

16) T.Sontvedt and H. Frivold, "Low Frequency Variation of the Surface Shape of Tip Region Cavitation on Marine Propeller Blades and Corresponding Disturbances on Nearby Solid Boundaries", 11 th Symposium on Naval Hydrodynamics, ONR, 717 729 ( 1976).

17） S R 第 183 部会, “船尾振動・騒音の軽減を目的と したプロペラ及び船尾形状の研究”, 日本造船研究 協会研究資料 358（1983）.

18) T. Ten Wolde and A. De Brujin, "A New Method for the Measurement of the Acoustical 
Source Strength of Cavitating Ship Propellers", International Shipbuilding Progress 22 (255), 385 396 (1975).

19) D. Ross, Mechanics of Underwater Noise, (Pergamon Press, 1976).

20) N. A. Brown, "Cavitation Noise Problems and Solutions", Proc. International Symposium on Shipboard Acoustics, 21 38 (1976).

21) P. Abbot and D. Greeley, "Cavitation Noise Investigations", Symposium on Small Hydro Power Fluid Machinery 1984, ASME, 141 147 (1984).

22) Yu.L. Levkovskii, "Modeling of Cavitation Noise", Soviet Physics-Acoustcs 13 ( 3 ), 337 339 ( 1968 ).

23) C. Clay and H. Medwin, Acoustical Oceanography; Principles and Applications (John Willy and Sons, New York, 1977), P 340.

24）岡村尚昭, 浅野利夫, “プロペラキャビテーション雑 音の予測と実船計測”, 日本造船学会論文集 164 ,
43 53 (1988).

25）岡村尚昭, 大島明, “プロパルサによる振動・騒音研 究の最近の動向”, 次世代船開発のための推進工学 シンポジウム第 9 章, 日本造船学会, $275 \sim 314$ (1991).

26) Y. Lecoffre, P. Chantrel and j. Teiller, "Le Grand Tunnel Hydrodynamique (GTH) : France's New Large Cavitation Tunnel for Naval Hydrodynamic Research," Int. Symp. on Cavitation Research Facilities and Techniques, Boston (1987).

27) H. G. Payer, J. Friesh and E.-A. Weitendorf, "Hydrodynamic Considerations in the Design of HYKAT", 19 th Int. Towing Tank Conference Group Discussion, Madrid (1990).

28) W.A.Morgan, "David Taylor Research Center's Large Cavitation Tunnel”, 19 th Int. Towing Tank Conference Group Discussion, Madrid (1990). 